\title{
Transversal Skills in Vocational Education and Training: The Case of ENSAM Engineering Students
}

\author{
Toufik El Ajraoui, PhD \\ Mohamed V University, Morocco \\ Khalid Ben Kaddour, PhD \\ Moulay Ismail University, Morocco \\ Mohammed Zeriouh, PhD \\ Sultan Moulay Slimane University
}

Doi:10.19044/esj.2019.v15n8p237～URL:http://dx.doi.org/10.19044/esj.2019.v15n8p237

\begin{abstract}
This study deals with $4^{\text {th }}$ year ENSAM (École Nationale Supérieure d'Arts et Métiers, Meknes, Morocco) engineering students who are studying English for engineering through Project-Based Learning (PBL). It attempts to describe how PBL helps develop students' transversal skills, namely critical thinking skills, interpersonal skills, and media and information literacy skills. The importance of such skills is reflected in the success of the learning process as well as the academic achievement of the targeted students. In addition, these skills get more importance when engineering students seek effective employability and successful integration in the job market. A field study has been carried out among 240 students who have responded to a close-ended questionnaire for a quantitative research in addition to a qualitative analysis of such numerical results. The analyzed findings reveal an overall positive response to the integration of PBL in the English class, stressing that this form of contextualized learning has helped the respondents develop the three sets of transversal skills above. General conclusions are presented and highlighted for other similar investigations.
\end{abstract}

Keywords: Transversal skills, vocational education, Project-Based Learning

\section{Introduction:}

This paper aims at highlighting the role that Project-Based Learning (henceforth PBL) at ENSAM plays in the students' learning process and outcome. For a background, in recent years, there has been a considerable shift in higher education from a focus on lecturing and rote supply of knowledge to students to a more active learner-centered approach stressing independent knowledge management and skills development. Putting students at the center 
of the teaching/learning process, recent educational research suggests scaffolding students in higher education to autonomously meet the roles expected from them in the different authentic situations, in which they need to mobilize ever-changing knowledge and skills for appropriate use and effective contribution. This goal illustrates in part why the $21^{\text {st }}$ century skills have been regularly inserted and tightly respected in schools of higher education, in order to prepare students for the requirements of modern education. These skills are usually narrowed down to communication, collaboration, critical thinking, creativity, digital literacy, leadership, and productivity. These concepts slightly vary from researcher to researcher, but they generally lie at the heart of what a $21^{\text {st }}$ century learner should possess to thrive while interacting with the local and global environments. $21^{\text {st }}$ century learners constantly veer towards a skill-based, cross-curricular and trans-disciplinary learning that fosters collaborative learning and reflective thinking. Collaborative learning in turn entails a personalization of the ways where content is dealt with and which can better cater for the differences and styles of learners. Viewing education from these lenses can encourage a learning/teaching experience that is firmly founded on the principles of some effective theories of learning such as cognitivism, social constructivism (Piaget, 1955), experientialism, discovery learning (Tuovinen \& Sweller, 1999), and connectivism (Siemens, 2005). These perspectives seek to take learners a step further from the mere memorization of content to a zone of proximal development where learning is effectively realized, skills are successfully mobilized, and creativity is constantly maximized (Daniels, 2005). To adopt these valuable theories informing our class practice, PBL has been adopted.

\section{The Conceptual Framework:}

This section explains in brief the three sets of transversal skills under study: Critical thinking skills, interpersonal skills, media and literacy skills. Critical thinking is, as synthesized in Shayakhmetova et al. (2017)'s extensive theoretical study of the concept, the intellectually disciplined "process of actively and skillfully conceptualizing, applying, analyzing, synthesizing, and/or evaluating information gathered from, or generated by, observation, experience, reflection, reasoning, or communication, as a guide to belief and action" (p. 230). The process of critical thinking implies a set of cognitive skills and operations rooted in Bloom (1956)'s taxonomies of the major levels of cognitive skills: recalling, understanding, applying, analyzing, synthesizing and evaluating. De Bono (1994) revised Bloom’s classification and introduced what he labels lateral thinking to the cognitive processes of learners as a higher order thinking skill. This label refers to creative thinking as a final stage that learners can reach after evaluating content. Therefore, creative and lateral thinking for De Bono (1994) are the ultimate stages learners can reach after 
the evaluation stage suggested by Bloom (1956). These tenets underlie the components of the process of critical thinking. For the second set of soft skills - interpersonal skills, there has been a consensus among applied linguists that possessing interpersonal skills refers to having a communicative competence that implies different sub-competencies, namely grammatical, sociolinguistic, discourse, and strategic ones (Canale \& Swain, 1980). This founding distinction was preceded by Hymes's (1972). Students' interpersonal skills in this study are assessed to see whether the project-based instruction they take at the ENSAM engineering school helps them develop these interpersonal skills in their verbal and nonverbal communication, both inside and outside class. As regards media and information literacy, which is the third focus of the study, it refers to learners' skills and ability to access, identify, manage, evaluate, and use effectively different types of media and information technologies inside and outside the classroom. Since media and information literacy is beneficial in all domains, it "enables learners to master content and extend their investigations, become more self-directed, and assume greater control over their own learning" (The Association of College and Research Libraries, 2000). Not only does the term 'literacy' refer to learners' ability to use information and media resources, but it also refers to the ability to critically integrate and evaluate the use of these resources while preparing and presenting their projects before reflectively reporting on all the project stages both inside and outside class.

\section{Review of the Literature:}

Due to their significance in real life situations, a considerable body of knowledge has been published on the importance of transversal skills, with which students in higher education should be equipped to appropriately function in the job market. The present review of literature explores the three main transversal skills on which the present study is conducted, critical thinking skills, interpersonal skills, media and information literacy skills. Concerning the first set of skills, one of the most crucial roles of engineering schools is to take students beyond the mere remembering of information to a more effective stage of analyzing information and engaging critically in creating new alternatives in authentic situations that require a process of problem solving. Recent studies reveal that critical thinking education has a positive effect on problem solving skills and self-esteem of students (Azizi et al., 2018). In addition to self-esteem, there is also a strong link between having critical thinking skills and being happy in the classroom (Raeisoon, 2017). Although there is a strong correlation between academic achievement, reading habits and critical thinking dispositions, it can be claimed that Turkish EFL learners in higher education, for instance, still do have low levels of critical thinking, which means they are not able to think critically at a sufficient level 
(Giilten, 2017). Some studies also suggest including a program for the development of critical thinking education with a recommended metric by which to measure critical thinking skills in the air force education in the American context (Stone, 2017). In their day-to-day practice, teachers need to plan for structured higher-level interactions for questioning to be effective and critical rather than ask for a recall for data only (Nappi, 2017). Lessons based on critical thinking together with an appropriate assessment of this capacity can transform students' achievements to considerable levels across the different branches of higher education. Incorporating an explicit criticalthinking curriculum has resulted in a significant improvement in medical education sub-domains like deduction, evaluation, and inference after the completion of the critical-thinking curriculum (Cone et al., 2016). Equally, systematically designed subject matter instruction on the development of domain-specific and domain-general critical thinking skills with an implicitly embedded focus on the targeted critical thinking outcomes as a component of the domain-specific classroom activities can instigate the development of critical thinking skills (Tiruneh et al., 2016). Thus, both deductive and inductive approaches for equipping students with critical thinking skills have proven effective with noted differences and specificities. Being transversal skills, critical thinking skills can be mobilized by students as interdisciplinary life skills from a domain to another, be it language, medicine, engineering, or other, depending on their future needs.

The present paper also explores the prominence of engineering students' interpersonal skills that emanates from their need to appropriately and effectively communicate in the potential different social settings in the job market. Since communication skills are considered vital by academic society and the world of business, engineering graduates need an ever-increasing interest in these skills to keep up with the current ever-changing states of the global market. Although students' attitudes towards the use of communicative methods in professional English language learning are positive, students still face difficulties such as those related to these language areas: word formation, multiple word choice, use of grammatical structures and speech clichés in dialogue and written speech, in addition to theoretical knowledge and skills on how to make a good presentation (Toropoviene, 2017). Actually, as regards the personal, social and emotional profiles in the fields of computer engineering education, there is a "considerable discrepancy between the level of competencies evidenced by university degree students and those deemed necessary by professionals for professional practice [; therefore,] there is a need to incorporate personal, social and emotional skills into university programmes" (Pertegal-Felice et al., 2014, p. 1198). When teaching interpersonal skills in online learning environments, studies have found that one problem that students face is lack of practice. This is because cognitive 
"understanding of interpersonal skills does not automatically lead to successful skills execution; for this reason, learners need to practice the newly acquired skill” (Doo, 2006, p. 264). The notion of practice is at the heart of experiential learning that helps students apply and use the acquired skills and information in new situations. Experiential learning is said to be a solution to this lack of practice that some " 'non-professional' activities like volunteering can be actively incorporated into students' learning process, making their overall experience of higher education more active, enjoyable and relevant for the development of a wide range of soft skills” (Khasanzyanova, 2017, p. 363). Knowing that interpersonal skills facilitate engagement, interaction, and collaboration between students, research "has shown a more immediate benefit of collaboration, in that this more active form of learning can also positively influence students' achievement, persistence, and attitudes about learning” (Bowen, 2000; Prince, 2004; Springer, Stann, \& Donovan, 1999, Qtd in Drobot, 2017, p. 433). Empirical research provides evidence that taking part in experiential activities in the form of extracurricular activities develops interpersonal skills and professional behaviors (Awatif, 2012). The importance of professional interpersonal communication for engineering students is also accentuated by research; absence "of 'real-life target' for written communication, such as a letter recipient, makes the task abstract and the learner confused and de-motivated" which pushes teachers to look for opportunities for their students to practice professional writing and interpersonal communication (Orlova \& Zeidmane, 2011, p. 523). These interpersonal skills are considered central assets for life-long learning.

Developing life-long learners necessitates another set of transversal skills: Media and information technology skills, which is the third axis of focus in this paper. Information literacy remains an indispensable part of an effective learner's profile in the pursuit of knowledge; it involves recognizing when information is needed and being able to efficiently locate, accurately evaluate, effectively use, and clearly communicate information in various formats. Research shows that "technologies are valuable tools in the learning processes and should enable peer communication, evaluation and exchange thus collaboration; enhance self-representation and presentation skills” (Petrea, 2015, p. 124) Research also shows that the complementary relationship between computational thinking and media and information literacy can give teachers a variety of skills to help students both navigate with a critical thinking and produce digital content in a creative way (Gretter \& Yadav, 2016). Research has identified that there still exists a student need of appropriate use of media and information tools both at the doctoral and the undergraduate levels in higher education. Although doctoral students for instance use information and communication technologies, when "it comes to relevance and use, the information literacy skills of doctoral students may lack 
depth, particularly in relation to Web search results” (Spezi, 2016, p. 102). These students who are considered to be far more advanced than undergraduates still lack some traditional criteria in their search to test the validity, credibility, and reliability of their web results such as "content soundness, author name, affiliation, or journal title, [which] are very little used for Web results” (Ibid). As noted above, in a globalized and hyper-connected society, research suggests putting critical thinking skills, interpersonal skills, and media and information literacy skills at the center of interest in modern higher education. Updated research reveals that these transversal skills are rewarding assets for learners who will have different profiles in different fields of interests and job markets, either locally or globally, after graduation.

\section{Methodology:}

This section provides an analysis of the methodology adopted in the present article. The issues investigated are rooted in the realities experienced in the TEFL context and based upon the research findings related to Projectbased instruction and its importance in learning English as a foreign language. Westwood (2008) believes that PBL represents an approach to studentcentered learning based on the constructivist principles. In other words, this study features project-based instruction and collaborative learning in the teaching of English for engineering students, hoping to investigate the impact of this learning method on three different students' transversal skills, mainly critical thinking skills, interpersonal skills, and media and information literacy skills.

\subsection{Quasi-Experimental Design:}

This research is undertaken to test the impact of PBL on developing engineering students' transversal skills. Having opted primarily for a quasiexperimental design, four sections of engineering students have been randomly chosen to participate in the study. It uses the mixed methods, also referred to as triangulation, which allows the individual researcher to have freedom of choice when selecting methods, techniques, and procedures of research to best meet his needs and purposes (Cherryholmes, 1992; Murphy, 1990). As will be described below, in this mixed methods study, both quantitative and qualitative data are used to investigate the research problem from different angles. Indeed, Gravetter \& Wallnau (2000) state that "mixed methods studies have some definite strength; since they include both qualitative and quantitative data, they provide a more complete picture of a situation than would either type of data by itself" (p. 443). The instruments and the analytical procedures used to probe the various aspects of the research questions raised in the study are explained below. 
Two hundred and forty $4^{\text {th }}$ year students took part in the study. They participated in the study during the second semester of the 2017/2018 academic year. The participants, 20 to 25 years old, 140 males and 100 females, are from different regions of Morocco, with different linguistic and communicative abilities as well as social and cultural backgrounds. They are divided into four sections. They study English for engineering through the PBL method in which they are made responsible for understanding and assimilating the content of the assigned course. This method revolves around projects that promote authentic, collaborative, and autonomous learning (Thomas, 2000; Curtis, 2002; Solomon 2003).

\subsection{Quantitative Measurements}

In general, for quantitative measurements, researchers use instruments that provide a standardized framework in order to limit data collection to certain predetermined responses or analysis categories (Patton, 1980). In the present study, it is important to validate the effects of PBL through numerical evidence in critical thinking, interpersonal, and media and information literacy skills' development. In this sense, using quantitative methodologies is effective in improving reliability of scores gained from instruments (Fraenkel \& Wallen, 2003). It can provide "assessment of validity through a variety of procedures with reliance on statistical indices, preference for breaking down complex phenomena into specific parts of analysis, and willingness to manipulate aspects, situations, or conditions in studying complex phenomena" (Fraenkel \& Wallen, 2003, p. 431). In particular, descriptive statistical methods are practical to investigate the relationships and patterns of behavior in terms of numbers. They are used to describe such behavioral patterns, employ "probabilistic arguments to generalize findings from samples to population of interest" (Rudestam \& Newton, 1992, p.24). A survey is used in order to investigate the attitude of students toward the effect of using PBL on the transversal skills under study. Based on the 5-point Likert scale, ranging from 'strongly disagree' to 'strongly agree', the survey is administered at the end of the semester after the course is totally covered. This survey takes the form of a questionnaire, containing twenty statements that are comprehensively based on our action research. These statements are assigned a name and a label and are designed to investigate three major factors in this questionnaire: F1: Critical thinking skills, F2: interpersonal skills, and F3: media and information literacy skills. F1 and F2 include 8 statements each while F3 introduces 4 statements as it is presented in the table below. 


\begin{tabular}{|c|c|c|}
\hline F1: Critical thinking skills & F2: Interpersonal skills & $\begin{array}{l}\text { F3: Medial and literacy } \\
\text { skills }\end{array}$ \\
\hline $\begin{array}{l}\text { S1: Evaluating } \\
\text { presentations helps me } \\
\text { improve my verbal } \\
\text { communication techniques. } \\
\text { S2: Evaluating } \\
\text { presentations helps me } \\
\text { improve my non-verbal } \\
\text { communication techniques. } \\
\text { S3: Evaluating slide } \\
\text { projection helps me master } \\
\text { my slide design standards. } \\
\text { S4: Critically listening to } \\
\text { presentations helps me } \\
\text { assimilate the course } \\
\text { content. } \\
\text { S5: Critically listening to } \\
\text { presentations helps me } \\
\text { receive the presenters' } \\
\text { message in a clear way. } \\
\text { S6: Receiving feedback } \\
\text { from my classmates helps } \\
\text { me improve my } \\
\text { presentational skills. } \\
\text { S7: Receiving feedback } \\
\text { from my teacher helps me } \\
\text { improve my presentational } \\
\text { skills. } \\
\text { S8: Writing the project } \\
\text { report helps me evaluate } \\
\text { my group members' } \\
\text { contribution. }\end{array}$ & $\begin{array}{l}\text { S9: Delivering } \\
\text { presentations helps me } \\
\text { improve my verbal } \\
\text { communication techniques. } \\
\text { S10: Delivering } \\
\text { presentations helps me } \\
\text { improve my non-verbal } \\
\text { communication techniques. } \\
\text { S11: Asking questions } \\
\text { enriches my interpersonal } \\
\text { skills. } \\
\text { S12: Interacting with } \\
\text { classmates boosts my } \\
\text { interpersonal skills. } \\
\text { S13: Collaborating with my } \\
\text { group members to finalize } \\
\text { the project develops my } \\
\text { organizational skills. } \\
\text { S14: Distributing roles } \\
\text { among my group members } \\
\text { to finalize the project } \\
\text { promotes my organizational } \\
\text { skills. } \\
\text { S15: Managing presentation } \\
\text { delivery time improves my } \\
\text { organizational skills. } \\
\text { S16: Intergroup } \\
\text { collaboration in the } \\
\text { classroom favours a better } \\
\text { interpersonal } \\
\text { communication. }\end{array}$ & $\begin{array}{l}\text { S17: Designing } \\
\text { presentation slides helps me } \\
\text { master the slide standards. } \\
\text { S18: Using social networks } \\
\text { in my project development } \\
\text { raises my information } \\
\text { literacy level. } \\
\text { S19: Writing the project } \\
\text { report enriches my } \\
\text { information literacy } \\
\text { background. } \\
\text { S20: Emailing the project } \\
\text { report to the teacher } \\
\text { enriches my information } \\
\text { literacy background. }\end{array}$ \\
\hline
\end{tabular}

The analysis of the obtained data contains 209 valid questionnaires responses, including 4180 points of view, where 1672 points of view are concerning F1, 1672 points of view are concerning F2, and 836 points of view are concerning F3. This data is handled by using SPSS.

\subsection{Qualitative Data:}

The quantitative data collected for the purpose of the study relies on numerical evidence. They are supported by qualitative data that are essential to understand the nature of things, referring to their meanings, concepts, definitions, characteristics, and descriptions. Quality refers to the what, how, when, and where of a thing. To be more precise, qualitative data deeply brings about significant information. Indeed, Maxwell (1996) confirms the idea of the far-reaching and in-depth information, saying that "the strengths of 
qualitative research derive primarily from its inductive approach, its focus on specific situations or people, and its emphasis on words rather than numbers" (p.17). The survey used for the purpose of the study will be subjected to a qualitative analysis that goes beyond the statistical numerical analysis. Indeed, without the bringing-in of the qualitative analysis, it would be impossible to understand why students adopt a specific attitudinal statement towards developing transversal skills, relying only on numerical analysis, count or measure. This type of analysis stems from our experience as practitioners who have been involved in teaching the sample students through PBL.

\section{The Study}

In this section, the results of the study are reported for the issues under investigation. These results include both the quantitative and qualitative analyses of the collected data used for the purpose of analyzing the effect of project-based instruction on engineering students' development of transversal skills achievement in English, mainly critical thinking skills, interpersonal skills, and media and information literacy skills. The findings have confirmed the claims that PBL has a positive impact on developing these skills. The probe into the collected data has been encoded and categorized to produce numerical information that could be generalized to the target population. Therefore, it was possible to statistically quantify, analyze, and summarize the collected information in such a way that this article will enable its readers to see what the data reveal about the target population. As mentioned above, the purpose of this study is to investigate the role of PBL in improving our respondents' transversal skills. The survey's questions were mainly designed to determine the causal relationship that may exist between PBL and these transversal skills.

\subsection{Results and Analysis}

From the collected data, results reveal that PBL has an immediate impact on transversal skills. In fact, the majority of students agree that the learning process has positively developed their critical thinking, interpersonal, and media and information literacy skills as can be discovered in the following graph. More details concerning each of the investigated factors will be outlined and displayed in the subsequent paragraphs. 


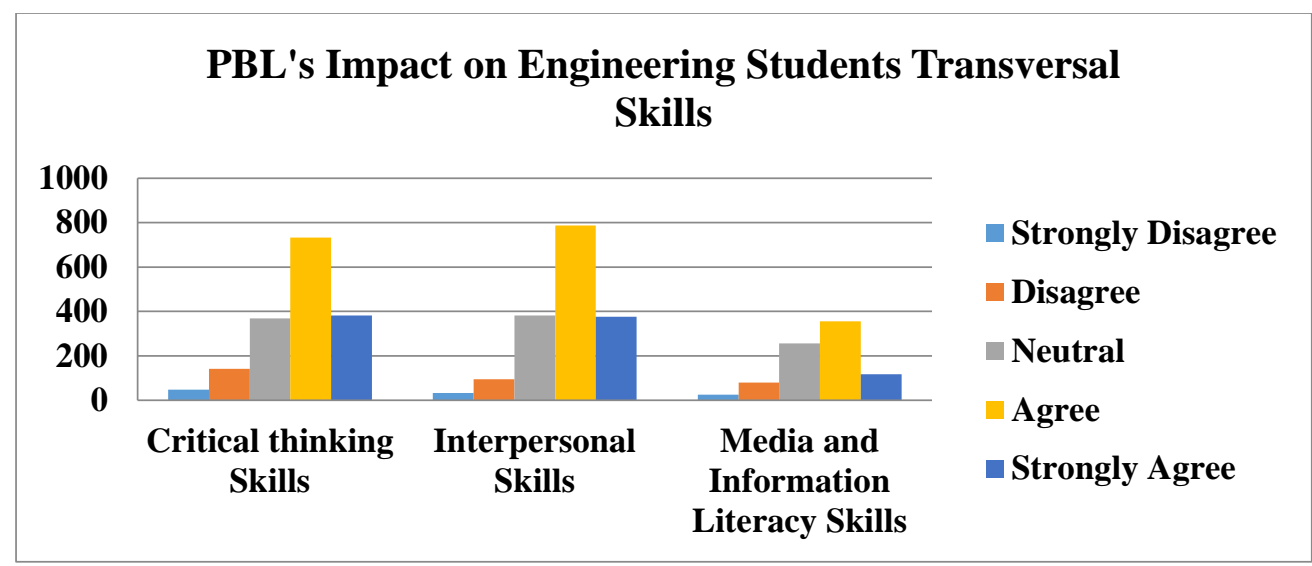

The first investigated factor F1 gives out that the majority of participants, which is the accumulation of 1114 positive responses out of 1672 points of view, agree with the eight statements that cover critical thinking skills. Statistically speaking, $44 \%$ and $23 \%$ respectively agree and strongly agree with the F1 eight statements as shown in the pie chart below.

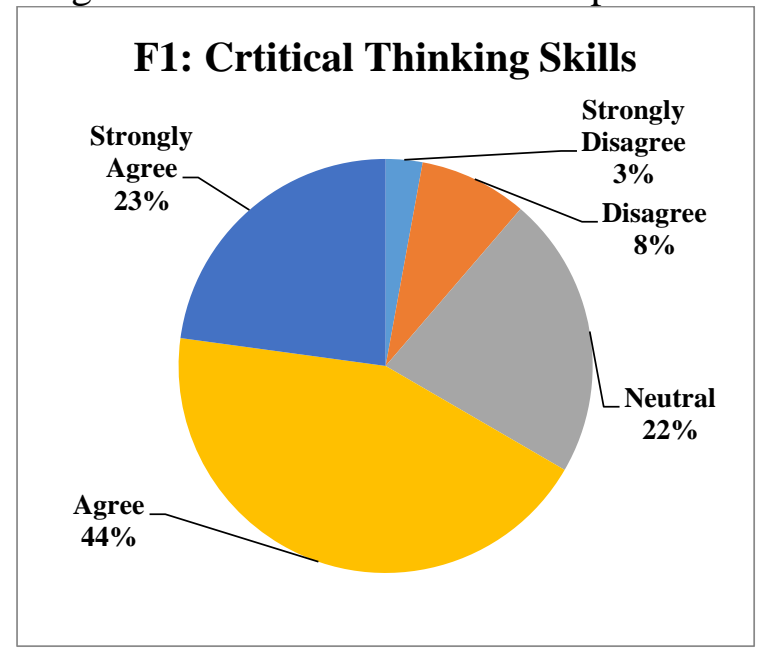

For our participants, evaluating presentations and slide projection, namely S1, S2, and S3, helps them improve their verbal and nonverbal communication techniques and their slide design standards. S4 and S5 which concern the respondents' critical listening to presentations help them assimilate the message and improve their presentational skills. S6 and S7, meaning receiving feedback from classmates and teacher helps improve their presentational skills. Through writing the project report, S8, they improve their group members' contribution. From this result, it has been found out that critical thinking skills are boosted with PBL as the statistics register the second high percentage of the collected data. Evaluation, critical listening, reception 
of feedback, and project report writing significantly allow the target students to achieve progress in their learning.

The second investigated factor F2 communicates very meaningful results on the interpersonal skills' eight statements, from S9 to S16. The statistics reveal that the total number of 1164 positive response out of 1672 registered points of view stress the importance of interpersonal skills. The highest percentage of $47 \%$ and $22 \%$ respectively agree and strongly agree with the eight statements as displayed in the pie chart below.

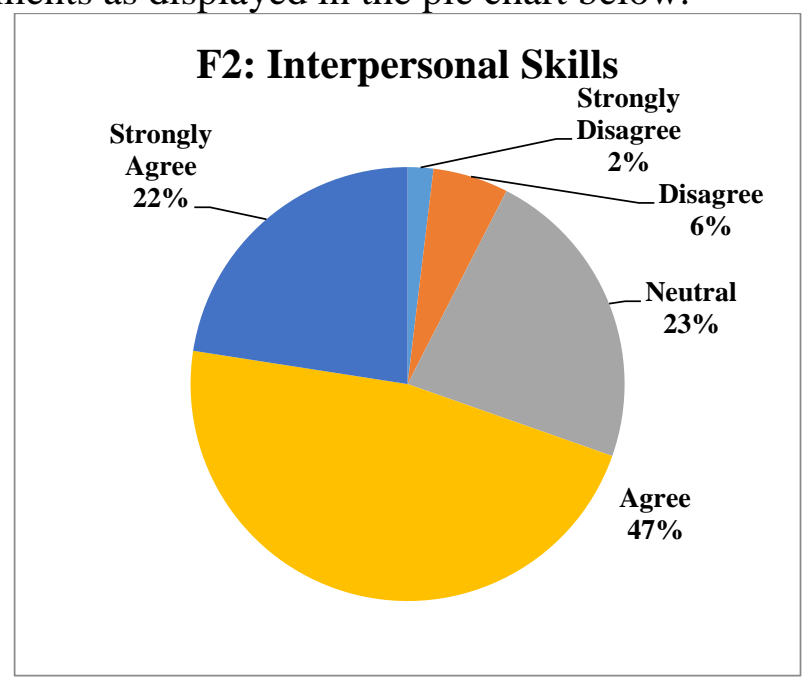

The above numerical results specifically reveal that, delivering presentations, S9 and S10, helps improve verbal and nonverbal communication techniques. Other skills such as interacting with classmates, collaborating with team members, distributing roles among team members, managing presentation delivery, S11, S12, S13, S14, and S15 respectively, all help develop organizational skills; whereas, intergroup collaboration in class, S16, favors better interpersonal communication. These results prove the respondents' urgent need for interpersonal skills which make their learning easier and faster. In fact, this outcome justifies the essence of PBL that is strictly based on interaction, collaboration, role distribution, and delivery management. The end product is better communication techniques, interpersonal skills, organizational skills, and interpersonal communication.

The last investigated factor F3, media and information literacy skills, in which 4 statements are at stake, exhibits that most respondents, $43 \%$ and $14 \%$ respectively agree and strongly agree with the statements $17,18,19$, and 20, namely that designing presentation slides helps master the slide standards, that using social networks in their project development raises their information literacy, that writing the project report and emailing the project to the teacher enrich their information literacy background. 


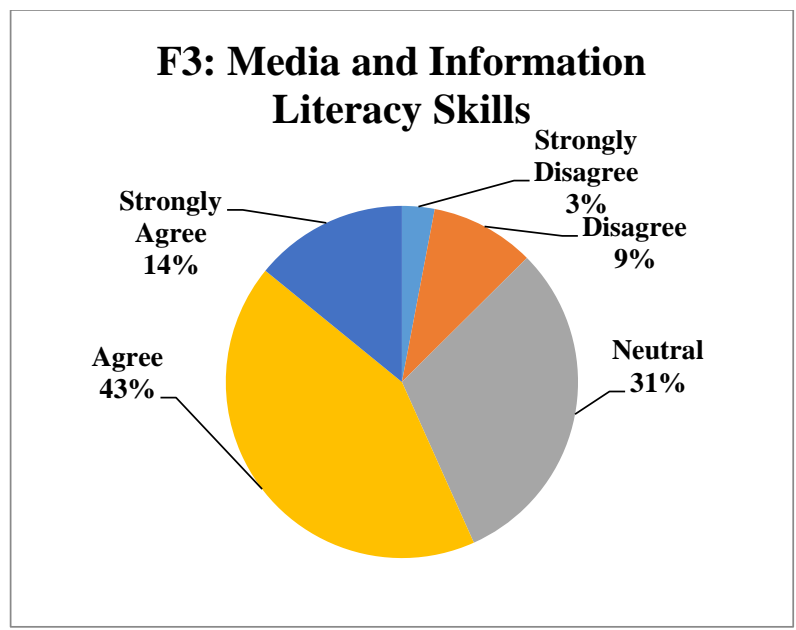

From these results, it can be stated that PBL reinforces the respondents' media and information literacy skills, which they need not only in this language course but also in other content subjects like mathematics and computer science.

\subsection{Implications}

The overall result of the present study implies that, with PBL, transversal skills are more beneficial advantages for ENSAM students who major in various engineering streams and profiles and target after graduation very competitive and ever changing job markets either nationally or internationally. The results of critical thinking skills suggest that the target students who recognized the importance of evaluating slide design, critically listening to presentations, and receiving feedback from their audience can achieve lateral thinking when they write their project report as a creative approach to their learning. It is their opportunity to reflect on their experience in a new light. Their positive response also means that they can exploit this transversal skill in other engineering fields of study depending on their present and future needs. As to interpersonal skills, the results which evince the importance of communication, interaction, and collaboration entail that these engineering students are now engaged in an active form of learning that can positively affect their academic and professional life-long efforts. The results concerning media and literacy skills are meaningful in the sense that in this digital age the participants believe that technologies are indispensable means in their learning as they lead them to information recognition, location, evaluation, effective use, and clear communication in different formats. By implication, their responses asserted that media and information literacy allows them to effectively communicate with peers, accurately evaluate information, collaborate with others, and significantly amplify their self- 
representation and presentation skills through the use of technology resources both inside and outside their language class.

\section{Conclusion:}

The results obtained in the study have proved that PBL was appreciated by ENSAM students as implied in the positive feedback that the questionnaires generated. Using both a qualitative and a qualitative approach to data, the findings display an overall positive response to the three transversal skills addressed, critical thinking skills, communication skills, media and information literacy skills. Thus, these findings can motivate more teachers, at the national and the global levels, to integrate PBL in their day-today practice, giving up some control over their classes and allowing more chances for learners to take responsibility of their learning process. Teachers might need to expand the learning time range that starts in class and extends to the library, home, other institutions, and digital tools beyond class. In the present study, learners showed different levels of engagement, social interaction, contextualized learning, cognitive processes, and use of digital resources throughout the different cycles of their projects. These are deemed to be at heart of the learning theories mentioned in the introduction for this paper: cognitivism, social constructivism, discovery learning, experientialism, and connectivism. Teams showed high engagement in the task to find ways to answer the driving questions of their projects. This search for answers can be said to have enhanced learners' deep learning through the process of investigation, comparison, research, data collection, critical reflection, and utilization of meaningful content anchored in real-life situations with the help of digital media. The process of inquiry that students were involved in sought to meet long-term goals that reigned in learners' minds throughout the entire semester. This itself changed and perverted the traditional understanding of the class practice that usually bases on short-term objectives met in class. This process encouraged what students knew, understood, and did in a continuum of transfer of language and knowledge to multiple new contexts. This was a method of inquiry and search for knowledge through experience, permitting some space for content negotiation and adaptation, then voice and choice among the members of each team. Students also had enough time to revisit their projects each moment, evaluate it, and modify it to meet the specificities of the task and the audience. The use of technology tools facilitated organizing information and presenting them in more dynamic, visible and interactive modes. Learners also had a chance to compare their projects to other contents worldwide on the web then benefit from others' experiences, which helped in self-/peer-evaluation and task adjustment. By and large, PBL positively altered the ENSAM $4^{\text {th }}$ year engineering students, yet this experience might 
require another study in other different learning environments to compare the usefulness and effectiveness of teaching through projects.

\section{References:}

1. Antic, D., \& Spacic, A. (2012). Project-based learning in English for Medecine. Acta Medica Medianae, 51(2), 50-55.

2. Awatif A. J., (2012). Developing Interpersonal Skills and Professional Behaviors through Extracurricular Activities Participation: a Perception of King Abdulaziz University Medical Students. JKAU: Med. Sci., 19. (4), 3-24.

3. Azizi M. et al., (2018). Effect of Critical Thinking Education on Problem Solving Skills and Self-Esteem in Iranian Female Students. Journal of Clinical and Diagnostic Research, 12(1), 6.

4. Benkaddour, K. (2014). Developing Project-Based Instruction in ESP Classrooms: The Case of ENSAM Engineering Students. (Unpublished doctoral thesis). Moulay Ismail University, Meknès, Morocco.

5. Bergh, V. V. D., Mortelmans, D., Spooren, P., Petegem, P. V., Gijbels, D., \& Vanthournout, G. (2006). New Assessment Modes within Project-Based Education - The Stakeholders. Studies in educational evaluation, 32, 345-368

6. Bilova, S. (2016). ICT in an ESP Classroom - Looking for a Balance, Conference Proceedings, $9^{\text {th }}$ Conference Edition, 294-297.

7. Bloom, B.S., (1956). Taxonomy of Educational Objectives, Handbook 1: The Cognitive Domain. New York: Longman.

8. Bono, D. E. (1994). Parallel thinking: From Socratic Thinking to De Bono Thinking, Australia: Penguin Books.

9. Canale, M. \& Swain, M. (1980). Theoretical Bases of Communicative Approaches to Second Language Teaching and Testing. Applied Linguistics (1). 1. 1-47.

10. Cherryhomes, C. H. (1992, August-September). Notes on Pragmatism and Scientific Realism. Educational Researcher, 14, 13-17.

11. Chuchalin, A. I. \& Danilova, E. A. (2005). The Breakthrough of the Internet to Empower ESP Teaching and Learning at Tomsk Polytechni University. Global J. of Engng. Educ., Vol.9, No.2, 129-136.

12. Cone, C ., (2016). Incorporation of an Explicit Critical-Thinking Curriculum to Improve

Pharmacy Students' Critical-Thinking Skills. American Journal of Pharmaceutical Education 2016; 80 (3).1-5

13. Curtis, D. (2002). The Power of Projects. Educational Leadership, 5053. 
14. Daniels, H. (2005). An Introduction to Vygotsky (2 $\left.{ }^{\text {nd }} e d.\right)$. London: Routledge.

15. Devlin-Scherer, R. (2005). Teaching for Real Learning: Classroom Applications, Grades 4-12 (pp.23-87). Lanham, MD: Rowman \& Littlefield Publishing Group.

16. Doo, M. Y, (2006). A Problem in Online Interpersonal Skills Training: Do Learners Practice Skills? Open Learning, 21 (3), Routledge. 263272.

17. Drobot I., (2017). Teaching English Technical Terms in the Domain of Hydrology with Cooperative Learning. AC-ETeL, Multidisciplinary Academic Conference, 430-436.

18. Fraenkel, J. R., \& Wallen, N.E. (2003). How to Design and Evaluate Research in Education ( $5^{\text {th }}$ ed.). New York: McGraw Hill.

19. Frankl, G. \& Bitter, S. (2013). Collaboration Is Smart: Smart Learning Communities. A. Holzinger and G. Pasi (Eds.): HCI-KDD 2013, LNCS 7947, pp. 293-302.

20. Giannakos, M. N., Jaccheri, L., \& Krogstie, J. (2016). How Video Usage Styles Affect Student Engagement? Implications for VideoBased Learning Environments. In State-of-the-Art and Future Directions of Smart Learning (pp. 157-164). Springer Berlin Heidelberg.

21. Giilten G E., (2017). The Relationship between Academic Achievement, Reading Habits and Critical Thinking Dispositions of Turkish Tertiary Level EFL Learners. Educational Research Quarterly, 41.(2). 43.

22. Gravetter, F.J., \& Wallnau, L.B. (2000). Statistics for the Behavioral Sciences $\left(5^{\text {th }}\right.$ ed.). Belmont, CA: Wadsworth/Thomson Learning.

23. Gretter S. \& Yadav A., (2016) Computational Thinking and Media \& Information Literacy: An Integrated Approach to Teaching Twenty-First Century Skills. Tech Trends, Springer, 60. 510-516.

24. Hammond, J., \& Gibbons, P. (2001). What is Scaffolding? In J. Hammond (Ed.), Scaffolding: Teaching and Learning in Language and Literacy Education (pp.1-14). Newtown, NSW, Australia: PETA.

25. Harrison, R. (2004). The Convergence of Community and Communication Online Communities and Japanese Language Education. Retrieved from http:/www.lib.kobeu.ac.jp/repository/00523021.pdf

26. Ibboston, M. (2008). English for Engineering. Cambridge: Cambridge University Press. 
27. Iijima, M., Murrow, P. J., and Hattori, M. (2010), Teaching English Language Skills to Students of Engineering in Japan. IFAC Proceedings Volumes, 42(24), 268-271.

28. Khasanzyanova, A., (2017). How Volunteering Helps Students to Develop Soft Skills. Int Rev Educ. 63. Springer, p.p. 363-379.

29. Kim, T., Cho, J. Y., \& Lee, B. G. (2013). Evolution to Smart Learning in Public Education: A Case Study of Korean Public Education. In Open and Social Technologies for Networked Learning (pp. 170-178). Springer Berlin Heidelberg.

30. Markham, T., Mergendoller, J., Larmer, J., \& Ravitz, J. (2003). Project-Based Learning Handbook. Canada: Buck Institute for Education.

31. Maxwell, J. A. (1996). Qualitative Research Design: An Interactive Approach (Applied social research methods series: Vol. 41). Thousand Oaks, CA: Sage Publications.

32. Murphy, J.P. (with Rorty, R.). (1990). Pragmatism: From Peirce to Davidson. Boulder, CO: Westview Press.

33. Nappi, J. S, (2017). The Importance of Questioning in Developing Critical Thinking Skills, The Delta Kappa Gamma Bulletin: International Journal for Professional Educators (84).1. (30). 30-41.

34. Nishigaki, C., \& Chujo, K. (2005). Using Call to Bridge the Vocabulary gap. Essential Teacher 2 (4), 40-43.

35. Orlova, I. \& Zeidmane A., (2011). Problems in Professional English Writing Skills Development for Students of Engineering Sciences, $10^{\text {th }}$ International Scientific Conference Engineering for Rural Development, Engineering for Rural Development, May 26-27, 2011, Latvia, 520-523.

36. Patton, M. C. (1980). How to Use Qualitative Methods in Evaluation. Beverly Hills, CA: Sage Publications.

37. Pereira de Eca, M. T. (2005). Using Portfolios for External Assessment: An Experiment in Portugal. International Journal of Art \& Design Education, 24(2), 209-218.

38. Petrea, G., (2015). Technologies in Class of the English for Specific Purposes. Intertext 3. (35). Chişinău, ULIM, 124-130.

39. Pertegal-Felices, M. L. et al., (2014). Differences between the Personal, Social and Emotional Profiles of Teaching and Computer Engineering Professionals and Students. Studies in Higher Education, 39 (7), Routledge, 1185-1201.

40. Piaget, J. (1955). The Child's Construction of Reality. London: Routledge \& Kegan Paul. 
41. Raeisoon, M. R et al., (2017). Comparing Skills of Critical Thinking and Happiness among Students of Faculty of Medial Sciences and other Universities of Ghaen. FMEJ 7; (1). March 25, 2017. (3). 3-7.

42. Rudestam, K. E., \& Newton, R. R. (1992). Surviving your Dissertation. Newbury Park, CA: SAGE Publications.

43. Sarich, E. (2014). A Guide to Planning and Executing a TOEIC Preparation Course. The Language Teacher: 38 (1), 17-21.

44. Shayakhmetova, D. et al., (2017). The Development of Critical Thinking Skills in Foreign Language Classroom, Astra Salvensis, 227240.

45. Sidman-Taveau, R. L. (2005). Computer-Assisted Project Based Learning in Second Language: Case Studies in Adult ESL. PhD Thesis. The University of Texas at Austin.

46. Siemens, G. (2005). Connectivism: A Learning Theory for the Digital Age. International Journal of Instructional Technology and Distance Learning, 2(1). Retrieved from http://www.itdl.org/journal/Jan_05/articleol.htm

47. Solomon, G. (2003). Project-Based Learning: A Primer. T\&L Magazine, 23(6).

48. Spezi, V., (2016). Is Information-Seeking Behavior of Doctoral Students Changing?: A Review of the Literature (2010-2015) New Review of Academic Librarianship . 22 (1) Routledge p.p. 78-106

49. Sthapornnanon, N., Sakulbumrungsil, R., Theeraroungchaisri, A., \& Watcharadamrongkun, S. (2009). Social Constructivist Learning Environment in an Online Professional Practice Course. American Journal of Pharmaceutical Education, 73(1), Article 10.

50. Stone, C., A. J., (2017). Critical Thinking Skills in USAF Developmental Education Air \& Space Power Journal. (53). p.p. 5267.

51. Sung, M. (2015). A Study of Adults’ Perception and Needs for Smart Learning. Social and Behavioral Sciences, 191, 115-120.

52. Talcott, C. \& Tullis, G. (2007). Target Score. $2^{\text {nd }}$ Ed. Cambridge: Cambridge University Press.

53. The Association of College and Research Libraries (2000). Information Literacy Competency Standards for Higher Education. Chicago, IL: The Association of College and Research Libraries. $\quad$ Retrieved October 16, 2008, $<$ http://www.ala.org/ala/mgrps/divs/acrl/standards/standards.pdf $>$

54. Thomas, J. W. (2000). A Review of Research on PBL. http://www.bobpearlman.org/BestPractices/PBL Research.pdf

55. Tiruneh, D. T. et al., (2016). Systematic Design of a Learning Environment for Domain-specific and Domain-General Critical 
Thinking Skills. Education Tech Research Dev, Springer, (64). 481505.

56. Toropoviene, S., (2017). Use of Communicative Methods to Enhance Professional Language Learning. Professional Studies: Theory and Practice. 3 (18).

57. Tuovinen, J. E., \& Sweller, J. (1999). A Comparison of Cognitive Load Associated with Discovery Learning and Worked Examples. Journal of Educational Psychology,91(2),334-341.

58. Tsiplakides, I., Fragoulis, J., \& Keramida, A. (2011). Content-Based Instruction in the Teaching of English as a Foreign Language. Review of European Studies, 3(1), 115-121.

59. Westwood, P. (2008). What Teachers Need to Know about Teaching Methods. Camberwell, Vic.: ACER Press. 